\title{
PENGARUH GOOD CORPORATE GOVERNANCE TERHADAP KINERJA KEUANGAN PERUSAHAAN PADA SEKTOR PERTAMBANGAN YANG TERDAFTAR DI BURSA EFEK INDONESIA PERIODE 2016-2019
}

\author{
Eva Irene Nababan, Robinhot Gultom ${ }^{\varpi}$, Mislan Sihite \\ Program Studi S1 Manajemen, Universitas Methodist Indonesia, Medan, Indonesia \\ Email: robinhot22@yahoo.com
}

DOI: https://doi.org/10.46880/methoda.Vol11No3.pp156-164

\begin{abstract}
This study aims to know and analyze the influence of Good Corporate Governance on corporate financial performance of the mining company sector listed on Indonesia Stock Exchange (BEI) period 2016-2019. The population are the mining company sector in Indonesia Stock Exchange period 2016-2019, which amounted to 47 companies and the sampling technique with purposive sampling, based on the criteria specified only 8 companies that meet the criteria. Methods of data analysis using multiple linear regression analysis. The results of this study partially indicate that the institusional ownership does not have an significant impacton the company's performanc as measured by ROE. The results partially indicate of managerial ownership does not have an significant impacton the company's performance. The independent commissioner partially indicate have an significant impacton the company's performance and the committee audit partially indicate does not have an significant impacton the company's performance. Simultaneously, the institusional ownership, the managerial ownership, the independent commissioner and the committee audit have an significant impact on the company's performance as measured by ROE.
\end{abstract}

Keyword: Good Corporate Governance, Corporate Financial Performance.

\begin{abstract}
ABSTRAK
Penelitian ini bertujuan untuk mengetahui dan menganalisis pengaruh Good Corporate Governance terhadap kinerja keuangan perusahaan pada sektor pertambangan yang terdaftar di BEI periode 2016-2019. Yang menjadi populasi dalam penelitian ini adalah perusahaan sektor pertambangan yang terdaftar di BEI Periode 2016-2019 sebanyak 47 perusahaan dengan menggunakan teknik pengambilan sampel yaitu purposive sampling sehingga sampel yang digunakan adalah 8 perusahaan. Metode analisis data yang digunakan dalam penelitian ini adalah analisis linier berganda. Hasil penelitian ini menunjukkan bahwa secara parsial KI tidak berpengaruh terhadap ROE, KM tidak berpengaruh terhadap ROE, KI berpengaruh terhadap ROE dan KA tidak berpengaruh terhadap ROE. Secara simultan Kepemilikan Institusional, Kepemilikan Manajerial, Komisaris Independen dan Komite Audit berpengaruh terhadap Return On Equity dengan nilai koefisien determinasi $\left(\mathrm{R}^{2}\right)=24,9 \%$ yang artinya adalah variabel Kepemilikan Institusional, Kepemilikan Manajerial, Komisaris Independen dan Komite Audit mempengaruhi Return On Equity sebesar 24,9\% sedangkan sisanya 75,1\% dipengaruhi oleh variabel lain yang tidak diteliti.

Kata Kunci: Good Corporate Governance, Kinerja Keuangan Perusahaan.
\end{abstract}




\section{PENDAHULUAN}

Good corporate governance digunakan untuk mengatur hubungan antara berbagai pihak internal dan eksternal dalam suatu organisasi demi tercapainya tujuan organisasi. Good corporate governance pada penelitian ini diproksikan dengan kepemilikan institusional, kepemilikan manajerial, komisaris independen dan komite audit. Para investor meyakini bahwa perusahaan yang menerapkan good corporate governance selalu berupaya untuk meminimalkan risiko sehingga meningkatkan kinerja keuangan perusahaan. Kinerja keuangan perusahaan pada penelitian ini diproksikan dengan Return On Equity (ROE). ROE merupakan rasio yang mengukur kemampuan perusahaan menghasilkan laba berdasarkan modal tertentu (Hamdani, 2016).

Kepemilikan Institusional merupakan kepemilikan saham oleh pemerintah, institusi keuangan, institusi berbadan hukum, institusi luar negeri, dana perwalian serta institusi lainnya pada akhir tahun. Hasil penelitian terdahulu menunjukkan bahwa kepemilikan institusional memiliki pengaruh terhadap kinerja perusahaan yang diukur dengan ROA dan ROE (Kurnianto, Sudarwati, \& Burhanudin, 2019). Sedangkan hasil penelitian lain dengan variabel yang sama menunjukkan kepemilikan institusional tidak memiliki pengaruh terhadap kinerja keuangan yang diukur oleh ROE (Situmorang \& Simanjuntak, 2019).

Kepemilikan manajerial merupakan jumlah kepemilikan saham oleh pihak manajemen dari seluruh modal perusahaan yang dikelola. Hasil penelitian terdahulu menunjukkan bahwa kepemilikan manajerial berpengaruh terhadap kinerja keuangan (Amyulianthy, 2012). Sedangkan hasil penelitian lain menunjukkan bahwa kepemilikan manajerial tidak berpengaruh terhadap kinerja keuangan (Putra \& Nuzula, 2017).

Komisaris independen merupakan komisaris yang tidak ada hubungan keluarga atau hubungan bisnis dengan direksi maupun pemegang saham. Hasil penelitian terdahulu menunjukkan bahwa komisaris independen memiliki pengaruh terhadap kinerja keuangan perusahaan (Kurnianto et al., 2019). Sedangkan hasil penelitian lain menunjukkan bahwa komisaris independen tidak memiliki pengaruh terhadap kinerja keuangan (Septiana, Hidayat, \& Sulasmiyati, 2016).

Komite audit merupakan komite tambahan yang dibentuk oleh dewan komisaris. Semakin besar proporsi komite audit akan semkakin besar juga fungsi monitoring pada komite audit terhadap pihak manajemen. Hasil penelitian terdahulu menunjukkan bahwa variabel komite audit memiliki pengaruh signifikan terhadap kinerja keuangan (Kho \& Prima, 2020). Sedangkan hasil penelitian lain menunjukkan bahwa komite audit tidak memiliki pengaruh terhadap kinerja keuangan (Situmorang \& Simanjuntak, 2019).

Penelitian ini memiliki tujuan untuk menguji dan menganalisis pengaruh Kepemilikan institusional, Kepemilikan Manajerial, Komisaris independen dan Komite audit terhadap kinerja keuangan perusahaan pada sektor Pertambangan yang terdaftar di Bursa Efek Indonesia baik secara parsial maupun secara simultan.

\section{KAJIAN PUSTAKA DAN \\ PENGEMBANGAN HIPOTESIS}

\section{Kinerja Keuangan}

Pengukuran kinerja keuangan dalam penelitian ini menggunakan rasio profitabilitas yaitu Return On Equity (ROE). Rasio profitabilitas merupakan rasio yang digunakan perusahaan untuk menghitung laba yang diperoleh dalam suatu periode tertentu. Dalam (Hamdani, 2016) Return On Equity (ROE) merupakan rasio yang mengukur kemampuan perusahaan menghasilkan laba berdasarkan modal tertentu. Rasio ini merupakan ukuran profitabilitas dari sudut pandang pemegang saham.

\section{Good Corporate Governance}

Menurut komite Cadburry dalam (Manossoh, 2016) good corporate governance adalah prinsip yang mengarahkan dan mengendalikan perusahaan agar mencapai keseimbangan antara kekuatan serta kewenangan perusahaan dalam 
memberikan pertanggungjawabannya. Menurut SK Menteri BUMN Nomor: Kep. 117/MMBU/2002 tentang Penerapan Praktek Good Corporate Governance dalam (Sedarmayanti, 2012) dijelaskan bahwa prinsip-prinsip good corporate governance meliputi transparansi, kemandirian, akuntabilitas dan kewajaran untuk pencapaian penyelenggaraan kegiatan usaha yang memperhatikan kepentingan setiap pihak yang terkait dalam penyelenggaraan kegiatan usaha, berlandaskan peraturan perundangundangan dan praktik-praktik yang berlaku umum.

\section{Pengaruh Kepemilikan Institusional Terhadap ROE}

Kepemilikan institusional merupakan proporsi kepemilikan saham yang dimiliki oleh institusi. Adanya kepemilikan oleh investor institusional akan mendorong peningkatan pengawasan yang lebih optimal terhadap kinerja manajemen, karena kepemilikan saham mewakili suatu sumber kekuasaan yang dapat digunakan untuk mendukung atau sebaliknya terhadap kinerja manajemen. Dalam (Herdinata \& Pranatasari, 2020) tingkat kepemilikan institusional yang tinggi akan mengarah kepada upaya pengawasan yang lebih besar yang dilakukan oleh kelembagaan investor untuk mencegah perilaku oportunistis manajer.

\section{Pengaruh Kepemilikan Manajerial Terhadap ROE}

Kepemilikan manajerial merupakan salah satu mekanisme yang dapat dipergunakan agar pengelola melakukan aktivitas sesuai dengan kepentingan pemilik perusahaan. Meningkatkan kepemilikan manajerial dapat digunakan sebagai cara untuk mengatasi masalah keagenan. Dalam (Rahmawati, 2016) $\mathrm{Hu}$ dan Izumida menyebutkan kepemilikan manajerial yang tinggi akan mendorong manajer mencurahkan kemampuannya untuk kreatif dan melindungi mereka dari penyalahgunaan sumber daya sehingga manajer akan bertindak memaksimalkan kinerja perusahaan atau shareholder.

\section{Pengaruh Komisaris Independen Terhadap ROE}

Komisaris independen adalah anggota dewan komisaris yang tidak memiliki hubungan keuangan, kepengurusan, kepemilikan saham dan atau hubungan keluarga dengan anggota dewan komisaris lainnya direksi dan atau pemegang saham pengendali atau hubungan lain yang dapat mempengaruhi kemampuannya untuk bertindak independen. Menurut (Hadi, 2011) yang menyatakan keberadaan komisaris independen dimaksudkan untuk menciptakan iklim yang lebih objektif dan mampu memberikan keseimbangan berbagai kepentingan pihak serta memberikan perlindungan terhadap kepentingan pemegang saham minoritas.

\section{Pengaruh Komite Audit Terhadap ROE}

Komite audit merupakan suatu kelompok yang sifatnya independen atau tidak memiliki kepentingan terhadap manajemen dan diangkat secara khusus serta memiliki pandangan antara lain bidang akuntansi dan hal-hal lain yang terkait dengan sistem pengawasan internal perusahaan. Perusahaan yang memiliki komite audit biasanya manajemen perusahaan lebih transparan dan terbuka. Menurut (Hasnati, 2014) komite audit sekurang-kurangnya terdiri tiga orang yang melaksanakan tugas penting yang berkaitan dengan sistem pelaporan keuangan.

\section{Pengaruh Good Corporate Governance Terhadap Kinerja Keuangan}

Dalam (Hamdani, 2016) good corporate governance (GCG) terbukti berpengaruh terhadap kinerja keuangan. ROE yang tinggi menunjukkan kinerja keuangan yang baik, yang mengakibatkan investor tertarik menanamkan modalnya. Sebaliknya, jika ROE yang rendah menunjukkan kondisi kinerja keuangan yang tidak baik, sehingga investor kurang tertarik menanamkan modal pada perusahaan yang bersangkutan. Berdasarkan penelitian (Putra \& Nuzula, 2017) variabel dewan komisaris independen, kepemilikan institusional, dewan direksi dan komite audit berpengaruh secara simultan terhadap kinerja perusahaan. 


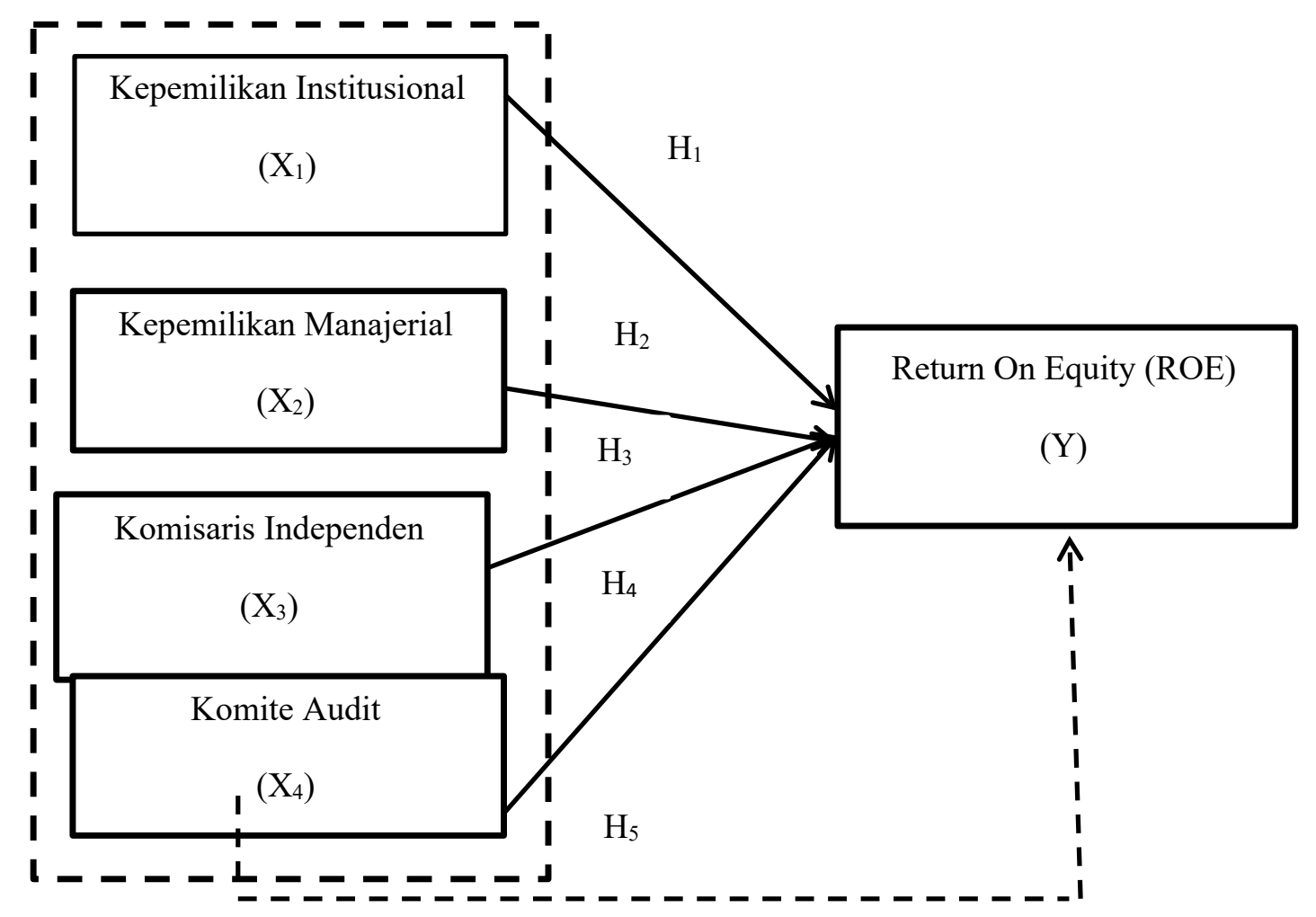

Gambar 1. Kerangka Berpikir

\section{METODOLOGI PENELITIAN}

\section{Jenis dan Sumber Data}

Jenis penelitian yang digunakan dalam penelitian ini adalah metode kuantitatif. Metode penelitian kuantitatif adalah metode penelitian yang berlandaskan pada filsafat positivisme, digunakan untuk meneliti pada populasi atau sampel tertentu, analisis data bersifat statistik dengan tujuan untuk menguji hipotesis yang telah ditetapkan (Sugiyono, 2018). Data dalam penelitian ini adalah laporan keuangan perusahaan pertambangan yang terdaftar di Bursa Efek Indonesia.

\section{Populasi dan Sampel}

Jumlah populasi perusahaan sektor pertambangan yang terdaftar di Bursa Efek Indonesia sebanyak 47 perusahaan. Sampel adalah sebagian dari populasi. Sampel dalam penelitian ini dipilih dengan menggunakan purposive sampling yaitu teknik pengambilan sampel sumber data dengan pertimbangan tertentu. Sampel pada penelitian ini sebanyak 8 perusahaan.

\section{Metode Pengumpulan Data}

Metode pengumpulan data yang digunakan dalam penelitian ini adalah metode kepustakaan dan metode dokumentasi.

\section{Definisi Operasional Variabel}

\section{Kepemilikan Institusional}

$$
\mathrm{KI}=\frac{\text { Jumlah saham yang dimiliki oleh institusi }}{\text { Jumlah total saham biasa }} \times 100 \%
$$

\section{Kepemilikan Manajerial}

$$
\mathrm{KM}=\frac{\text { Jumlah saham yang dimiliki Direksi dan Komisaris }}{\text { Jumlah total saham biasa }} \times 100 \%
$$


Komisaris Independen

$\mathrm{KI}=\frac{\text { Jumlah dewan komisaris independen }}{\text { Jumlah total dewan komisaris }} \times 100 \%$

Komite Audit

Komite Audit $=$ Jumlah Anggota Komite Audit

Return On Equity (ROE)

$\mathrm{ROE}=\frac{\text { Laba Bersih }}{\text { Total Ekuitas }} \times 100 \%$

\section{Metode Analisis Data}

Metode analisis data adalah metode yang digunakan untuk menganalisis data dalam rangka memecahkan masalah atau menguji hipotesis. Pengolahan data menggunakan SPSS versi 25 (Stastical Program for Social Sciences versi 25). Hasil pengolahan dengan menggunakan SPSS versi 25.

\section{Statistik Deskriptif}

Menurut (Sugiyono, 2018) statistik deskriptif adalah statistik yang digunakan untuk menganalisis data dengan cara mendeskripsikan atau menggambarkan data yang telah terkumpul sebagaimana adanya tanpa bermaksud membuat kesimpulan yang berlaku untuk umum atau generalisasi.

\section{Uji Asumsi Klasik}

\section{Uji Normalitas}

Dalam (Ghozali, 2018) uji normalitas bertujuan untuk menguji apakah dalam model regresi, variabel pengganggu atau residual memiliki distribusi normal. Uji normalitas dilakukan dengan uji One Sample KolmogorovSmirnov.

\section{Uji Multikolinieritas}

Pengujian ini bertujuan untuk menguji apakah di dalam model analisis regresi ditemukan adanya korelasi antar variabel bebas (independen). Untuk mendeteksi ada tidaknya multikolinieritas dalam regresi dapat diuji dengan menggunakan nilai variance inflation factor (VIF).

\section{Uji Heteroskedastisitas}

Uji Heteroskedastisitas bertujuan untuk menilai apakah dalam model regresi terjadi ketidaksamaan varians dari residual satu pengamatan ke pengamatan yang lain.

\section{Uji Autokorelasi}

Dalam (Ghozali, 2018) uji autokorelasi bertujuan untuk menguji apakah dalam model regresi linier ada korelasi antara kesalahan penganggu pada periode $\mathrm{t}$ dengan kesalahan penganggu pada periode $\mathrm{t}-1$ (sebelumnya). Model regresi yang baik adalah regresi yang bebas dari autokorelasi. Pengujian dengan autokorelasi dilakukan dengan menggunakan Durbin-Watson (DW).

\section{Analisis Regresi Linier Berganda}

Analisis regresi linier berganda merupakan analisis yang jumlah variabel yang digunakan lebih dari dua yaitu satu variabel dependen dan selebihnya adalah variabel independen.

$\mathrm{ROE}=\alpha+\beta_{1} \mathrm{KI}+\beta_{2} \mathrm{KM}+\beta_{3} \mathrm{KI}+\beta_{4} \mathrm{KA}+\varepsilon$

Keterangan:

$$
\begin{aligned}
& \mathrm{ROE}=\text { Return On Esset } \\
& \alpha=\text { Konstanta } \\
& \beta_{1}, \beta_{2}, \beta_{3}, \beta_{4}=\text { Koefisien Regresi } \\
& \mathrm{KM}=\text { Kepemilikan Institusional } \\
& \mathrm{KI}=\text { Kepemilikan Manajerial } \\
& \mathrm{KA}=\text { Komite Audit } \\
& \mathrm{KA}=\text { Komite Audit } \\
& \mathrm{KI}=\text { Komisaris Independen } \\
& \varepsilon=\text { Error }
\end{aligned}
$$




\section{Uji Hipotesis}

\section{Uji Signifikansi Simultan (Uji-F)}

Dalam (Ghozali, 2018) uji pengaruh bersama-sama (joint) digunakan untuk mengetahui apakah variabel independen secara bersama-sama atau jointmempengaruhi variabel dependen

\section{Uji Signifikansi Parsial (Uji-t)}

Dalam (Ghozali, 2018) uji parsial digunakan untuk mengetahui pengaruh masing-masing variabel independen terhadap variable dependen.

\section{Uji Koefisien Determinasi}

Koefisien determinasi $\left(\mathrm{R}^{2}\right)$ pada intinya digunakan untuk mengetahui sampai seberapa besar variabel terikat dipengaruhi oleh variabel bebas.

\section{HASIL DAN PEMBAHASAN}

\section{Uji Asumsi Klasik}

\section{Uji Normalitas}

Berdasarkan hasil uji normalitas dengan menggunakan One-Sample Kolgomorov Smirnov Test secara keseluruhan dengan membandingkan nilai Unstandadized Residual sebesar 0,128>0,005 yang artinya adalah secara keseluruhan data yang digunakan dalam penelitian ini adalah normal.

Tabel 1. Hasil Uji Normalitas ( $N$-Part Test) One-Sample Kolmogorov-Smirnov Test

\begin{tabular}{|c|c|}
\hline & $\begin{array}{c}\text { Unstandardize } \\
\mathrm{d} \text { Residual }\end{array}$ \\
\hline
\end{tabular}

\begin{tabular}{|c|c|c|}
\hline \multicolumn{2}{|l|}{$\mathrm{N}$} & 32 \\
\hline \multirow{2}{*}{$\begin{array}{l}\text { Normal } \\
\text { Parameters }{ }^{\mathrm{a}, \mathrm{b}}\end{array}$} & Mean & .0000000 \\
\hline & Std. Deviation & 69.483243566 \\
\hline \multirow{3}{*}{$\begin{array}{l}\text { Most Extreme } \\
\text { Differences }\end{array}$} & Absolute & .138 \\
\hline & Positive & .138 \\
\hline & Negative & -.129 \\
\hline \multicolumn{2}{|l|}{ Test Statistic } & .138 \\
\hline \multicolumn{2}{|c|}{ Asymp. Sig. (2-tailed) } & $.128^{\mathrm{c}}$ \\
\hline
\end{tabular}

\section{Uji Multikolinieritas}

Tabel 2. Nilai Tolerance dan VIF

\begin{tabular}{|l|l|r|r|}
\hline \multicolumn{2}{|l|}{ Model } & \multicolumn{2}{c|}{ Collinearity Statistics } \\
\cline { 3 - 4 } \multicolumn{2}{|l}{1} & Tolerance & \multicolumn{1}{c|}{ VIF } \\
\cline { 2 - 4 } & Constant) & & \\
\cline { 2 - 4 } & $\begin{array}{l}\text { Kepemilikan } \\
\text { Institusional }\end{array}$ & .356 & 2.805 \\
\cline { 2 - 4 } & $\begin{array}{l}\text { Kepemilikan } \\
\text { Manajerial }\end{array}$ & .375 & 2.666 \\
\cline { 2 - 4 } & $\begin{array}{l}\text { Komisaris } \\
\text { Independen }\end{array}$ & .715 & 1.399 \\
\cline { 2 - 4 } & Komite Audit & .789 & 1.268 \\
\hline
\end{tabular}

Berdasarkan tabel 2 dapat dilihat bahwa nilai tolerance setiap variabel lebih besar dari 0,1 dan nilai VIF setiap variabel di bawah 10 sehingga tidak terdapat hubungan atau korelasi antara satu variabel bebas dengan variabel bebas lainnya.

\section{Uji Heteroskedastisitas}

Uji park dilakukan dengan cara melakukan pemangkatan terhadap residual, lalu dilakukan transformasi LN (logaritma natural) kemudian melakukan regresi terhadap variabel independen. Hal ini dapat dilihat probabilitas signifikansinya $>0,05$ berarti tidak terjadi heteroskedastisitas.

Tabel 3. Hasil Uji Park

\begin{tabular}{|c|c|c|c|c|c|}
\hline \multicolumn{6}{|c|}{ Coefficients $^{\mathrm{a}}$} \\
\hline \multirow[t]{2}{*}{ Model } & \multicolumn{2}{|c|}{$\begin{array}{c}\text { Unstandardized } \\
\text { Coefficients }\end{array}$} & \multirow{2}{*}{$\begin{array}{c}\begin{array}{c}\text { Standardized } \\
\text { Coefficients }\end{array} \\
\text { Beta }\end{array}$} & \multirow[t]{2}{*}{$\mathrm{T}$} & \multirow[t]{2}{*}{ Sig. } \\
\hline & B & Std. Error & & & \\
\hline \begin{tabular}{l|l}
1 & (Constant)
\end{tabular} & 6.977 & 4.044 & & 1.725 & .096 \\
\hline $\begin{array}{l}\text { Kepemilikan } \\
\text { Institusional }\end{array}$ & -.044 & .027 & -.385 & -1.619 & .117 \\
\hline Kepemilikan Manajerial & -.010 & .024 & -.094 & -.407 & .687 \\
\hline Komisaris Independen & .106 & .038 & .461 & 2.745 & .011 \\
\hline Komite Audit & -.509 & .695 & -.117 & -.731 & .471 \\
\hline
\end{tabular}


Hasil uji park dalam tabel 3 dapat dilihat bahwa nilai signifikansi setiap variabel lebih besar dari 0,05 yang disimpulkan bahwa tidak terjadi heteroskedastisitas antara variabel independen dalam penelitian ini.

\section{Uji Autokorelasi}

Tabel 4. Uji Autokorelasi dengan Uji Durbin-Watson

\begin{tabular}{|l|r|r|r|r|r|}
\hline \multicolumn{5}{|c|}{ Model Summary $^{\mathbf{b}}$} \\
\hline $\begin{array}{l}\text { Mod } \\
\text { el }\end{array}$ & $\mathrm{R}$ & R Square & $\begin{array}{c}\text { Adjusted R } \\
\text { Square }\end{array}$ & $\begin{array}{c}\text { Std. Error of } \\
\text { the Estimate }\end{array}$ & Durbin-Watson \\
\hline 1 & $.588^{\mathrm{a}}$ & .346 & .249 & 74.4524594 & 1.309 \\
\hline
\end{tabular}

Berdasarkan Tabel 4 dapat dilihat bahwa nila DW 1,309 nilai ini akan dibandingkan dengan nilai tabel signifikansi 5\%, jumlah sampel $(\mathrm{n})=$ 32 dan jumlah variabel independen $(\mathrm{k})=4$ maka diperoleh nilai du 1,7323 dan nilai dl 1,1769 maka hasil DW adalah $1,1769 \leq 1,309 \leq 1,7323$ sehingga dapat disimpilkan penelitian ini tidak ada autokorelasi positif.

\section{Analisis Regresi Linier Berganda}

Tabel 5. Analisis Regresi Linier Berganda

\begin{tabular}{|c|c|c|c|c|c|c|}
\hline \multicolumn{7}{|c|}{ Coefficients $^{\mathrm{a}}$} \\
\hline \multirow{2}{*}{\multicolumn{2}{|c|}{ Model }} & \multicolumn{2}{|c|}{$\begin{array}{l}\text { Unstandardized } \\
\text { Coefficients }\end{array}$} & \multirow{2}{*}{$\begin{array}{c}\begin{array}{c}\text { Standardized } \\
\text { Coefficients }\end{array} \\
\text { Beta }\end{array}$} & \multirow[t]{2}{*}{$\mathrm{T}$} & \multirow[t]{2}{*}{ Sig. } \\
\hline & & $\mathrm{B}$ & Std. Error & & & \\
\hline \multirow[t]{5}{*}{1} & (Constant) & -126.773 & 172.696 & & -.734 & .469 \\
\hline & $\begin{array}{l}\text { Kepemilikan } \\
\text { Institusional }\end{array}$ & -.267 & 1.157 & -.060 & -.231 & .819 \\
\hline & Kepemilikan Manajerial & -.117 & 1.004 & -.029 & -.116 & .908 \\
\hline & Komisaris Independen & 5.025 & 1.643 & .563 & 3.058 & .005 \\
\hline & Komite Audit & -3.076 & 29.698 & -.018 & -.104 & .918 \\
\hline
\end{tabular}

Berdasarkan Tabel 5 diperoleh persamaan regresi linier berganda sebagai berikut: $\mathrm{ROE}=-126,773-0.267 \mathrm{KI}-0,117 \mathrm{KM}+5,025 \mathrm{KI}-3,076 \mathrm{KA}$

\section{Uji Hipotesis}

\section{Uji Signifikansi Simultan (Uji-F)}

Tabel 6. Uji Signifikansi Simultan (Uji - F)

\begin{tabular}{|l|l|r|r|r|r|r|}
\hline \multicolumn{7}{|l|}{ ANOVA $^{\text {a }}$} \\
\hline \multicolumn{2}{|l|}{ Model } & $\begin{array}{c}\text { Sum of } \\
\text { Squares }\end{array}$ & \multicolumn{1}{c|}{ Df } & Mean Square & F & Sig. \\
\hline \multirow{2}{*}{1} & Regression & 79091.730 & 4 & 19772.932 & 3.567 & $.018^{\mathrm{b}}$ \\
\cline { 2 - 8 } & Residual & 149665.555 & 27 & 5543.169 & & \\
\cline { 2 - 8 } & Total & 228757.285 & 31 & & & \\
\hline
\end{tabular}

Berdasarkan hasil pada tabel diatas diperoleh nilai $F_{\text {hitung }}$ adalah 3,567 lebih besar dari $F_{\text {tabel }}$ sebesar 2,728 $(3,567>2,728)$ sedangkan tingkat signifikansinya adalah 0,018 lebih kecil dari taraf signifikan yaitu $0,05(0,018<0,05)$. Dengan demikian, secara simultan kepemilikan institusional, kepemilikan manajerial, komisaris independen dan komite audit berpengaruh terhadap kinerja keuangan.

\section{Uji Signifikansi Parsial (Uji-t)}

Hasil uji signifikansi parsial dapat dilihat pada tabel 5 yaitu: Variabel kepemilikan institusional memiliki nilai $\mathrm{t}_{\text {hitung }}<\mathrm{t}_{\text {tabel }}$ dimana $\mid-$ 
$0,231 \mid<2,0518$ dengan tingkat signifikansi $0,819>0,05$ sehingga dapat dinyatakan bahwa kepemilikan institusional tidak berpengaruh terhadap variabel return on equity. Variabel kepemilikan manajerial memiliki nilai $t_{\text {hitung }}<$ $t_{\text {tabel }}$ dimana $|-0,116|<2,0518$ dengan tingkat signifikansi $0,886>0,05$ sehingga dapat dinyatakan bahwa kepemilikan manajerial tidak berpengaruh terhadap variabel return on equity. Variabel komisaris independen memiliki nilai $t_{\text {hitung }}>t_{\text {tabel }}$ dimana $3,058>2,0518$ dengan tingkat signifikansi $0,005<0,05$ sehingga dapat dinyatakan bahwa komisaris independen berpengaruh terhadap variabel return on equity. Variabel komite audit memiliki nilai $\mathrm{t}_{\text {hitung }}<\mathrm{t}_{\text {tabel }}$ dimana $|-0,104|<2,0518$ dengan tingkat signifikansi $0,918>0,05$ sehingga dapat dinyatakan bahwa komite audit tidak berpengaruh terhadap variabel return on equity.

\section{Koefisien Determinasi $\left(R^{2}\right)$}

Berdasarkan tabel 4 nilai koefisien determinasi terletak pada kolom Adjusted $R$ Square. Diketahui nilai koefisien determinasi sebesar 0,249. Nilai tersebut berarti seluruh variabel bebas yaitu kepemilikan institusional, kepemilikan manajerial, komisaris independen dan komite audit menjelaskan variabel return on equity sebesar 0,249 atau $24,9 \%$ dan sisanya sebesar $75,1 \%$ dijelaskan oleh variabel lain yang tidak diteliti.

Kepemilikan institusional tidak berpengaruh terhadap kinerja keuangan hal ini sesuai dengan nilai $t_{\text {hitung }}$ sebesar $|-0,231|$ lebih kecil dari nilai $\mathrm{t}_{\text {tabel }}$ sebesar 2,0518 $(|-0,231|<2,0518)$ dan nilai signifikansi 0,819 lebih besar dari 0,05 (0,819> 0,05). Hasil penelitian ini sejalan dengan penelitian Septiana dkk (2016) yang menunjukkan bahwa good corporate governance yang diproksikan dengan kepemilikan institusional tidak berpengaruh terhadap kinerja keuangan perusahaan yang diproksikan dengan return on equity (ROE).

Kepemilikan manajerial tidak berpengaruh terhadap kinerja keuangan perusahaan hal ini sesuai dengan nilai $t_{\text {hitung }}$ sebesar $|-0,116|$ lebih kecil dari nilai $t_{\text {tabel }}$ sebesar 2,0518 dan nilai signifikansi 0,908 lebih besar dari 0,05 (0,908 > $0,05)$. Hasil ini mendukung penelitian Putra dan Nuzula (2017) yang menunjukkan bahwa kepemilikan manajerial tidak berpengaruh terhadap kinerja keuangan perusahaan yang diproksikan dengan Return On Asset (ROA) dan Return On Equity (ROE).

Komisaris independen berpengaruh terhadap kinerja keuangan perusahaan hal ini sesuai dengan nilai tabel $2,0518(3,058>2,0518)$ dan nilai signifikansi 0,005 lebih kecil dari 0,05 $(0,005<0,05)$. Hasil penelitian ini sejalan dengan penelitian Kurnianto dkk (2016) yang menemukan bukti empiris bahwa good corporate governance yang diproksikan dengan komisaris independen memiliki pengaruh terhadap kinerja keuangan perusahaan yang diproksikan dengan Return On Asset (ROA) dan Return On Equity (ROE).

Komite audit tidak berpengaruh terhadap kinerja keuangan perusahaan hal ini sesuai dengan nilai $t_{\text {hitung }}$ sebesar $|-0,104|$ lebih kecil dari nilai $t_{\text {tabel }}$ sebesar $2,0518(|-0,104|<2,0518)$ dan nilai signifikansi 0,918 lebih besar dari 0,05 $(0,918>0,05)$. Hasil penelitian ini sama dengan penelitian terdahulu yang dilakukan oleh Putra dan Nuzula (2017) yang menunjukkan bahwa komite audit tidak berpengaruh terhadap kinerja keuangan perusahaan yang diproksikan dengan Return On Asset (ROA) dan Return On Equity (ROE).

Kepemilikan institusional, kepemilikan manajerial, komisaris independen dan komite audit berpengaruh terhadap kinerja keuangan perusahaan hal ini sesuai dengan dari nilai $F_{\text {hitung }}$ sebesar 3,567 lebih besar dari nilai $\mathrm{F}_{\text {tabel }}$ sebesar $2,728(3,567>2,728)$ dengan nilai signifikansi sebesar 0,018 . Nilai signifikansi tersebut lebih kecil dari $0,05(0,018<0,05)$.

\section{KESIMPULAN}

Berdasarkan hasil pengujian diperoleh kesimpulan sebagai berikut:

1. Komisaris independen secara parsial berpengaruh terhadap kinerja keuangan perusahaan.

2. Kepemilikan institusional, kepemilikan manajerial dan komite audit secara parsial 
tidak berpengaruh terhadap kinerja keuangan perusahaan.

3. Kepemilikan institusional, kepemilikan manajerial, komisaris independen dan komite audit secara simultan berpengaruh terhadap kinerja keuangan perusahaan.

4. Nilai koefisien determinasi sebesar 0,249. Nilai tersebut berarti seluruh variabel bebas yaitu kepemilikan institusional, kepemilikan manajerial, komisaris independen dan komite audit menjelaskan variabel return on equity sebesar 0,249 atau $24,9 \%$ dan sisanya sebesar $75,1 \%$ dijelaskan oleh variabel lain yang tidak diteliti.

\section{DAFTAR PUSTAKA}

Amyulianthy, R. (2012). Pengaruh struktur corporate governance terhadap kinerja perusahaan publik Indonesia. Liquidity, l(2), 91-98.

Ghozali, I. (2018). Aplikasi Analisis Multivariate dengan Program IBM SPSS Edisi 9. Semarang: Universitas Diponegoro Press.

Hadi, Z. (2011). Karakteristik Tanggung Jawab Pribadi Pemegang Saham Komisaris dan Direksi Dalam Perseroan Terbatas. Malang: UB Press.

Hamdani, S. (2016). Good Corporate Governance Tinjauan Etika Dalam Praktik Bisnis. Jakarta: Mitra Wacana Media.

Hasnati. (2014). Komisaris Independen \& Komite Audit. Yogyakarta: Absolute Media.

Herdinata, C., \& Pranatasari, F. D. (2020). Kajian Dan Solusi Manajemen Berbasis Riset Bagi Usaha Mikro Kecil Dan Menengah. Yogyakarta: Deepublish.

Kho, S., \& Prima, A. P. (2020). Pengaruh Good Corporate Governace dan Ukuran Perusahaan Terhadap Kinerja Perusahaan Yang Terdaftar di Bursa Efek Indonesia. Jurnal Akrab Juara, 5(3), 116-128.

Kurnianto, W. A., Sudarwati, S., \& Burhanudin, B. (2019). Mekanisme Good Corporate Governance Terhadap Kinerja Perusahaan Yang Terdaftar Di Jakarta Islamic Index (Jii) Tahun 2014-2016. Jurnal Manajemen Dan Keuangan, 8(1), 12-20.

Manossoh, H. (2016). Good Corporate Governace Untuk Meningkatkan Kualitas
Laporan Keuangan. Jakarta: PT. Norlive Kharisma Indonesia.

Putra, A. S., \& Nuzula, N. F. (2017). Pengaruh corporate governance terhadap profitabilitas (Studi pada perusahaan perbankan yang terdaftar di bursa efek indonesia periode 2013-2015). Jurnal Administrasi Bisnis, 47(1), 103-112.

Rahmawati, S. (2016). Konflik Keagenan dan Tata Kelola Perusahaan di Indonesia. Banda Aceh: Penerbit Syiah Kuala University Press.

Sedarmayanti. (2012). Good Governance (Kepemerintahan yang baik) dan Good Corporate Governance (Tata Kelola Perusahaan yang baik) (Rev. Editi). Bandung: Mandar Maju.

Septiana, N., Hidayat, R. R., \& Sulasmiyati, S. (2016). Pengaruh Mekanisme Good Corporate Governance Terhadap Profitabilitas Perusahaan (Studi Pada Perusahaan Makanan Dan Minuman Tahun 2011-2014). Jurnal Administrasi Bisnis, 38(2), 147-155.

Situmorang, C. V., \& Simanjuntak, A. (2019). Pengaruh Good Corporate Governance Terhadap Kinerja Keuangan Perusahaan Perbankan Yang Terdaftar Di Bursa Efek Indonesia. Jurnal Akuntansi Dan Bisnis, 5(2), 160-169.

https://doi.org/10.31289/jab.v5i2.2694

Sugiyono, P. D. (2018). Metode Penelitian

Kuantitatif, Kualitatif dan $R \& D$.

Bandung: Penerbit Alfabeta. 